NBER WORKING PAPER SERIES

\title{
RACE AND PREGNANCY OUTCOMES IN THE TWENTIETH CENTURY: A LONG-TERM COMPARISON
}

\author{
Dora L. Costa \\ Working Paper 9593 \\ http://www.nber.org/papers/w9593 \\ NATIONAL BUREAU OF ECONOMIC RESEARCH \\ 1050 Massachusetts Avenue \\ Cambridge, MA 02138 \\ March 2003
}

I have benefited from the comments of members of the March 2003 NBER/DAE meeting. I gratefully acknowledge the support of the Robert Wood Johnson Foundation and NIH grants R01 AG19637 and P01 AG10120. The views expressed herein are those of the authors and not necessarily those of the National Bureau of Economic Research.

(C2003 by Dora L. Costa. All rights reserved. Short sections of text not to exceed two paragraphs, may be quoted without explicit permission provided that full credit including Cnotice, is given to the source. 
Race and Pregnancy Outcomes in the Twentieth Century: A Long-Term Comparison Dora L. Costa NBER Working Paper No. 9593

March 2003

JEL No. I1, N3

\begin{abstract}
$\underline{\text { ABSTRACT }}$
Differentials between blacks and whites in birth weights and prematurity and stillbirth rates have been persistent over the entire twentieth century. Differences in prematurity rates explain a large proportion of the black-white gap in birth weights both among babies attended by Johns Hopkins physicians in the early twentieth century and babies in the 1988 National Maternal and Infant Health Survey. In the early twentieth century untreated syphilis was the primary observable explaining differences in black-white prematurity and stillbirth rates. Today the primary observable explaining differences in prematurity rates is the low marriage rate of black women. Maternal birth weight accounts for 5-8 percent of the gap in black-white birth weights in the recent data, suggesting a role for intergenerational factors. The Johns Hopkins data also illustrate the value of breast-feeding in the early twentieth century -- black babies fared better than white babies in terms of mortality and weight gain during the first ten days of life spent in the hospital largely because they were more likely to be breast-fed.
\end{abstract}

Dora L. Costa

MIT

50 Memorial Drive

Cambridge, MA 02142

costa@mit.edu

and NBER 


\section{Introduction}

In the United States today, African-Americans at all ages are in worse health than whites. They are more likely to be born premature and with lower birth weights for gestational age. They are more likely to die in infancy, in large part because they are born prematurely (Copper et al. 1993). At older ages a greater proportion of African-Americans are likely to report themselves in fair or poor health than whites in the same age group; a greater proportion report limits on activities of daily living; and a greater proportion report having specific chronic conditions, particularly hypertension, diabetes, and arthritis (Manton and Stallard 1997; Smith and Kington 1997). Explanations for black-white health differentials include the greater early life environmental stress faced by African-Americans, lifestyle differences in exercise and diet, differential access to medical care, and differences in income and education.

This paper documents the differential twentieth century trends in black and white pregnancy outcomes and examines what socioeconomic and maternal health factors explained these differentials in the past and in recent times. Examining pregnancy outcomes is important because health differentials in early life may have a long reach. Barker (1994) argued that measures of fetal and maternal malnutrition are related to such adult chronic conditions as ischaemic heart disease, adult-onset diabetes, and thyroid conditions. Doblhammer and Vaupel (2001) found that month of birth, a proxy for the disease and nutritional environment faced by the mother, influences adult life expectancy at ages greater than 49. Preston, Hill, and Drevenstedt (1998) found that among African-Americans survival to age 85 is best predicted by a farm background, having literate parents, and being from a two-parent household. Emmanuel et al. (1999) found that among all ethnic and racial groups studied in Washington state, there is an inverse relationship between maternal birth weight and infant low birth weight. They noted that the birth weights

of black mothers were markedly lower than those of white mothers and suggested that racial 
differences in pregnancy outcomes may be related to maternal prenatal factors. Thus a firstgeneration college-educated woman may still be carrying the risks of generations of poverty and this risk may be preprogrammed in utero in her children. This paper will use recent data to examine whether black-white differences in maternal birth weight can account for any of the black-white birth weight gap.

Relatively little is known about long-trends in black and white birth weight and stillbirth rates and even less about racial differentials in prematurity. Ward (1993) reported that black babies born at Boston Lying-In in the late nineteenth century were roughly 200 grams smaller than white babies, but that black babies' weight was comparable to that of babies born in Europe. Steckel (1986) used height at young ages to infer that at birth the mean slave baby weighted less than 2500 grams, suggesting severe deprivation. This paper uses records from Johns Hopkins Hospital in the first third of the century and recent data to analyze differential trends not only in birth weights, but also in prematurity and stillbirth rates, the probability of surviving the first ten days of life, and weight gain in the first ten days of life.

\section{Producing Healthy Babies}

Maternal nutrition and health is an important determinant of birth weight. Women with low prepregnancy weights and with inadequate weight gain tend to have smaller babies. But, the relationship between maternal nutrition and fetal growth is nonlinear; deprivation must pass a threshold level before birth weight is significantly affected because the fetus is protected at the expense of the mother (Tanner 1978). Infectious disease, alcohol or drug use, smoking, and heavy physical work can also reduce birth weight. The impact of these factors varies during gestation. Some are felt most strongly in the third semester, when fetal weight gain is greatest; others are felt most strongly during the first trimester when cell growth is the greatest. Inadequate prenatal 
care will also affect the development of the fetus, but in the past prenatal care was certainly less effective. $^{1}$

The effects of maternal nutrition and health may extend across generations. Mother's birth weight predicts children's birth weight. Using all births from the 1958 British birth cohort, Emanuel, Alberman, and Evans (1992) find that each 100 grams of maternal birth weight increases the birth weight of singleton births by 12 grams. Studies of maternal and paternal half-siblings find that the intrauterine environment accounted for more of the variance of birth weight than genetics (Morton 1955). Emanuel et al. (1999) argue that the lower birth weights of AfricanAmerican compared to white mothers may explain the persistence of black-white birth weight differentials.

Maternal infection predicts prematurity and stillbirths. Pre-term births are associated with bacterial vaginosis and previous genital infections. Such maternal infections as syphilis, toxoplasmosis, parvovirus B-19, chorioamnionitis, and Listeria monocytogenes have been implicated in intrauterine deaths. Other medical factors such as hemoglobinopathies and Rh sensitization also play a role (Copper et al. 1994). Mother's health may also play a role in stillbirths through placental insufficiency and intrauterine growth restriction (Petersson et al. 2002). Smoking is associated with both prematurity and stillbirths.

Other important determinants of stillbirths, prematurity, and birth weight are the factors that are specific to a pregnancy, such as the age of the mother, parity, the sex of the child, and the number of births. Birth weight rises at a decreasing rate with the age of the mother, parity, the spacing interval, and gestational age. Taller mothers have larger babies, male newborns tend to weigh about one hundred grams more than females, and multiple births are lighter than single

\footnotetext{
${ }^{1}$ In the first third of this century prenatal care was common only after the seventh month and consisted largely of instruction of the patient in diet, exercise, and hygiene; arrangements for confinement; desirability of nursing; the importance of regular medical exams to detect abnormalities, toxaemia, and eclampsia; and the danger signs of pregnancy (Speert 1980).
} 
births. In recent populations, prematurity is associated with teen births and with births to mothers older than 34. A high maternal age is also associated with intrauterine fetal death. Congenital malformations also predict stillbirths.

Today death in the first ten days of life is mainly due to congenital factors. At the beginning of the twentieth century babies faced a high risk of death from birth injuries. Based upon data from New York Lying-In, Costa (1998) estimated that at least one third of deaths were from birth injuries, often cerebral hemorrhage, suggesting that the fetal head was large in proportion to the size of the mother's pelvic outlet. Babies at New York Lying-In also failed to regain their birth weight by the tenth day, largely because they were fed only every four hours, sometimes even only every eight, rather than every two as recommended today.

Race plays a role in the determination of pregnancy outcomes as a proxy for income, acting as an enabling variable, that is one which permits the purchase of better nutrition or medical care. It may also be a proxy for health habits, for familial support, for exposure to stress, or for maternal health endowments. Researchers who regress pregnancy outcomes on race and omit these or other inputs will overestimate the impact of race.

Although race may partially proxy for unobservable income characteristics or for maternal nutrition and health, it is still of interest to establish the long-term trend in birth weight by race. In addition, I also examine whether once I control for all observable factors, differences in pregnancy outcomes by race still persist. This enables me to determine what some of the sources of pregnancy outcome inequality by race are.

\section{The Records of Johns Hopkins}

The proportion of births attended by physicians was rising rapidly in the United States at the beginning of the twentieth century, with most deliveries in the major cities attended by a physician 
even before 1920. In Baltimore in 1915, 74 percent of births to black married mothers were attended by a physician as were 73 percent of births to white, native-born married mothers (Rochester 1923). ${ }^{2}$ By 1935 for the country as a whole only 6 percent of white births were not attended by physicians. However, among blacks 55 percent of births were not attended by physicians, mainly because most births to blacks in rural areas (places less than 2,500 in population) were not physician attended. Thus in 194071 percent of rural black births were not attended by a physician compared to 19 percent of urban black births. Virtually all white births in 1940 in urban areas were physician attended. In cities of 250,000 or more, such as Baltimore, differences between black and white rates of physician attendance by 1940 and 1950 were small and most births were overseen by a physician (Vital Statistics of the United States, 1950).

Johns Hopkins Hospital was one of the foremost teaching hospitals in the country. It ministered to a wide population within Baltimore and the surrounding area, drawing from the nearby neighborhoods for within hospital births and from a wider area for home births supervised by Johns Hopkins physicians. The records of both the indoor and outdoor departments have been preserved in the hospital archives and the construction of the sample used in this research is described in the Data Appendix.

The sample used in this research spans the years 1897 to 1935 . Fifty-three percent of the sample consists of births to black mothers, at a time when roughly 17 percent of all births in the city of Baltimore were to black women. ${ }^{3}$ Black and white births were roughly proportionately divided between the indoor and outdoor departments. However, babies born in the indoor department were almost 300 grams lighter, were more likely to be premature, and had stillbirth rates that were more than twice as high. It was common practice for hospitals to bring

\footnotetext{
${ }^{2}$ Rates among the foreign-born were lower, ranging from a high of 65 percent among Jews to a low of 22 percent among Poles (Rochester 1923).

${ }^{3}$ See the 1922 edition of Birth, Stillbirths, and Infant Mortality Statistics.
} 
abnormal or complicated cases into the hospital, even when they occurred in the outdoor service (Louden 1992). As discussed in the Data Appendix, hospital births are undersampled. However, because the undersampling is too small to affect the results, unweighted results are presented.

The clientele of Johns Hopkins was predominately upper working class. In the late 1910s and 1920s, when some socio-economic data are available, 22 percent of white fathers and 63 percent of black fathers were laborers. No father held a professional occupation. Weekly earnings (in current dollars) were $\$ 20$ for white fathers and $\$ 16$ for black fathers. In contrast, in the United States as a whole 20 percent of all non-farm male workers were laborers and average weekly earnings in manufacturing were \$22 (United States Bureau of the Census, Series D 182-238: 139 and Series D 802-810: 170). A negligible portion of mothers of either race worked.

The records of Johns Hopkins show no evidence of unequal surgical treatment by race, even though all wards were segregated and served by the white staff. Despite the trend in American obstretics towards prophylactic forceps operation, the employment of version as a routine method of delivery, routine episotomy, induction of labor, and Caesarian sections, interference in the labor process at Johns Hopkins was not the norm. ${ }^{4}$ A negligible portion of mothers of either race were given any type of pain relief such as chloroform or ether. Forceps were used in roughly 10 percent of all births, regardless of race. Caesarian section rates were also comparable across races: roughly 1 percent of white births and 2 percent of black births.

The 1988 National Maternal and Infant Health Survey (NMIHS) is used to investigate black-white differentials in a modern population. ${ }^{5}$ This survey is a random sample of births in

\footnotetext{
${ }^{4}$ J. Whitridge Williams, a member of the Johns Hopkins faculty since 1896 who later became chairman of the obstretics department, denounced this trend at the annual meeting of the Medical Society of the State of New York in 1922 (Louden 1992: 352).

${ }^{5}$ Sanderson, Emanuel, and Holt (1995) used this survey to examine the effect of maternal birth weight on child birth weight among blacks and whites separately.
} 
1988 and contains both birth and death certificate and interview information. It oversamples low-birth-weight babies and all population means estimated from this survey are adjusted using the sampling weights. In the regressions (but not the sample means), only those observations for which maternal birth weight is known are used. Mothers who did not know their own birth weight tended to be older, unmarried, of higher parity, shorter, and less educated. Child characteristics did not predict the mother's knowledge of her own birth weight controlling for the mother's characteristics.

\section{Pregnancy Outcome Trends}

Table 1 illustrates that although the birth weights of both black and white babies born in hospitals in the early 1900s compare favorably to those of modern populations, the gap in black and white birth weights is persistent. There was roughly a 200 gram difference in the mean birth weight of black and white babies born at Johns Hopkins and at Boston Lying-In. There was a 240 gram difference in the median birth weight of black and white babies born at Johns Hopkins, compared to a 210 gram difference in 1998 for the United States as a whole. ${ }^{6}$ The proportion of babies weighing less than 2500 grams at birth has historically been roughly double among blacks. ${ }^{7}$

Since 1918, when national data on fetal deaths by race became available, fetal death rates have been falling for both races, but the black rate has been roughly twice that of whites (see Figure 1). In 1918 for every 1000 live births there were 80 stillbirths among blacks and 38 among whites. By 1950 the number of stillbirths per 1000 live births had fallen to 32 among blacks and 17 among whites. By 1996 fetal deaths per 1000 live births were 11 among blacks and 6 among

\footnotetext{
${ }^{6}$ In 1950, the black-white birth weight difference was only 70 grams and black births were up to 100 grams higher than in subsequent years. Why black babies fared so much better in 1950 is unclear.

${ }^{7}$ The weight of black babies was similar to that of babies born in Europe. For example, the mean weight of babies born at the Allgemeines Krankenhaus in Vienna between 1910 and 1930 was 3,143 grams (Ward 1993).
} 
whites.

Less is known about long-run racial trends in prematurity rates. In 1960, 6 percent of white births were premature (less than 37 weeks gestation) compared to 12 percent of black births. By 199810 percent of white births and 17 percent of black births were premature (Vital Statistics of the United States, various issues).

Tables 2 and 3 use the Johns Hopkins data and the 1988 NMIHS to illustrate long-run trends in pregnancy outcomes. The tables show a persistent gap in black and white prematurity rates. The tables also show that intrauterine deaths are rare today, but that in the past they averaged 12 percent of all births among blacks and 6 percent of all births among whites. Per 1000 live births these represent 132 fetal deaths among blacks and 66 fetal deaths among blacks, higher than the national averages but similar to fetal death rates for the city of Baltimore as a whole. ${ }^{8}$ Note that when birth weight is calculated for both stillbirths and live births, the data show a rising birth weight trend, suggesting that declining stillbirth rates may explain the constancy of live birth weight. Including stillbirths magnifies black-white birth weight differentials, particularly in the Johns Hopkins data.

Tables 2 and 3 also show that death in the first ten days of life is rare today. In the past, these early deaths were more common among whites than among blacks and white full-term babies who survived lost weight by day 10 whereas black babies gained weight.

\footnotetext{
${ }^{8}$ In 1922, the fetal death rate in Baltimore was 126 per 1000 live births among blacks and 58 per 1000 live births among whites (see the 1922 edition of Birth, Stillbirth, Infant Mortality Statistics).
} 


\section{Empirical Framework}

I examine the factors that mediate the effects of race on birth outcomes by running regressions of the form,

$$
\begin{array}{r}
y_{i}=\alpha+\delta W_{i}+u_{i} \\
y_{i}=\alpha+\delta W_{i}+\beta X_{i}+u_{i},
\end{array}
$$

where $y_{i}$ is the dependent variable, $W$ is a dummy equal to one if the child was white, $\mathrm{X}$ is a vector of control variables, and $\mathrm{u}$ is an error term. For the Johns Hopkins sample, I estimate probit regressions where the dependent variables are indicator variables equal to one if the child was born premature, was born stillborn, or died within 10 days of birth and I estimate OLS regressions where the dependent variables are equal to birth weight or weight gain during the ten days spent in the hospital. For the 1988 NMIHS, I estimate a probit regression where the dependent variable is an indicator variable equal to one if the child was born premature and I estimate OLS regressions where the dependent variable is birth weight. All regressions using the NMIHS are weighted.

I will examine how $\delta$, the coefficient on the white dummy, changes as I control for additional characteristics. Because the order in which additional characteristics are controlled for will determine whether controlling for one specific characteristic has a large effect, I will test for robustness by varying the order in which characteristics are controlled for. Note that this methodology assumes that the black and white birth weight production functions are the same. Running separate regressions for blacks and whites did not reveal any significant differences in the black and white birth weight production functions.

Table 4 lists the control variables in the Johns Hopkins sample used in the regressions

and shows how they differ by race. Black births were of lower gestational age, were more likely to be home births, were somewhat more likely to be to unmarried mothers, were to younger mothers, 
and were to mothers who were more likely to have syphilis. Black mothers were in labor longer and were more likely to breast-feed their children. The higher propensity of black mothers to breast-feed their children relative to white, native-born mothers in Baltimore was noted in the Children's Bureau study of infant mortality among babies born in 1915 (Rochester 1923).

The differences in maternal syphilis rates shown in Table 4 are particularly striking. During World War I the annual rate of rate of men infected with syphilis entering the army was 5 percent and that of men infected with gonorrhea was 23 percent (Brandt 1987: 231). A study of six southern rural counties by the Julius Rosenwald Fund and by the United States Public Health Service just before the Great Depression reported that in the richest county and the one with the best medical care (provided by the University of Virginia Hospital), syphilis rates among African-Americans were 8.9 percent whereas in the poorest county (which was also home of the later notorious Tuskegee Institute) syphilis rates were 39.8 percent (Parran 1937: 161-174). A widely advertised public health campaign carried out in Chicago between 1937 and 1940 which provided free syphilis tests and free treatment showed that syphilis rates could be sharply lowered with treatment. More than 60 percent of all cases treated under the Chicago program came from the city's black wards where health facilities were grossly inadequate and infection rates were high (Brandt 1987: 152). ${ }^{9}$

Table 5 shows how black and white mothers differ in terms of their characteristics in the 1988 NMIHS. Black mothers are of higher parity, are much less likely to be married, are younger, are less likely to be smokers, are less well-educated, are taller, gain less weight during their pregnancies, were born with a lower birth weight, and are less likely to breast-feed their

\footnotetext{
${ }^{9}$ Differential syphilis rates by race may explain the high rates of childlessness among ever married black women observed in metropolitan areas. In Baltimore, 17 percent of ever married black women age 40-49 were childless whereas only 8 percent of their white counterparts were. In all metropolitan areas of the United States the respective percentages were 18 and 12. In contrast, in non-metropolitan areas the proportion of ever married women age 40-49 who were childless was 9 percent among whites and 8 percent among blacks.
} 
children.

The two samples show a large increase in the proportion of unmarried black mothers, mirroring the trend for the nation as a whole. Ruggles (1994) reports that in 191095 percent of white children and 80 percent of black children age 0-4 were living with both parents. In 1980 87 percent of white children in that age group were living with both parents, but only 46 percent of their black counterparts were doing so.

In the Johns Hopkins sample, control variables in the preterm, stillbirth, and birth weight regressions include parity, parity squared, dummy variables equal to one if the child was male, if it was a home birth, and if the mother was married, the number of prenatal visits, the mother's age, a dummy equal to one if the mother was foreign-born, a dummy equal to one if the mother had syphilis, dummies indicating whether the birth was in the summer (June-August), fall (September-November), winter (December-February), and spring (March-May), and dummies indicating the decade of birth (before 1910, in the 1910s, and in the 1920s or later). The stillbirth and birthweight regressions also control for prematurity using a dummy variable or gestational age in weeks. Control variables in the death by day 10 regressions include birth weight, either a dummy variable for prematurity or gestational age in weeks, a dummy equal to one if the child was breast-fed, parity, parity squared, a dummy equal to one if the child was male, a dummy equal to one if the mother was married, the number of prenatal visits, the mother's age, dummy variables equal to one if the mother was foreign-born, if the mother had syphilis, if forceps were used, or if extraction was used, the observed length of labor in hours, seasonal dummies, and a dummy equal to one if the child was born in the 1920 s or later. Control variables in the weight gain regressions include dummy variables indicating if the child was fed breast-milk only, breast-milk and formula, or formula only, gestational age in weeks, parity, parity squared, a dummy equal to one if the child was male, a dummy equal to one if the mother was married, the number of prenatal visits, the mother's age, a dummy equal to one if the mother was foreign-born, a dummy 
equal to one if the mother had syphilis, seasonal dummies, and a dummy equal to one if the birth was in the 1920 s or later.

In the NMIHS, control variables in the prematurity regressions are parity, parity squared, dummies equal to one if the child was male or the mother was married, the mothers' age, dummies equal to one if the mother ever had a prenatal visit, was foreign-born, was a smoker, had high alcohol use (more than 8 drinks a week in the 3 months before finding out about the pregnancy), dummies for educational level (less than high school, high school, some college, and college), mother's height, and mother's birth weight. The birth weight regressions control for these factors as well as prematurity, gestational age, mother's weight gain, and mother's birth weight.

\section{Birth Outcomes and Race at Johns Hopkins}

Table 6 shows that maternal syphilis explains 33 percent of the difference in prematurity rates between black and white babies. Although maternal syphilis significantly predicts stillbirths, it does not explain differences in black-white stillbirth rates. Differences in black-white prematurity rates explain 41 percent of the difference in black-white stillbirth rates. No other observable factors explained differences in black-white prematurity or stillbirth rates.

The only observable characteristic that predicted differences in black-white birth weights was prematurity or gestational age. For all births, black-white differences in prematurity rates explained 18 percent of the difference in birth weights controlling for all other observables. Once prematurity was controlled for, maternal syphilis no longer had a statistically significant effect

on birth weight. For full-term births controlling for gestational age explained 9 percent of the difference between black-white birth weights controlling for all other observables.

A strongly significant predictor of birth weight was season of birth. Babies born in the spring (March-May) weighted 73 to 81 grams less than babies born in the summer (June-August), 
perhaps because of the nutritional stress their mothers experienced during the winter months. A study of a rural North Carolina mill town begun in 1939 found that in spring vitamin levels were at their lowest point (Beardsley 1987: 204). When season of birth was defined by quarter, then babies born during the second quarter (April-June) were significantly more likely to be born prematurely than babies born in other quarters. Season of birth did not predict stillbirth. ${ }^{10}$

Low birth weight babies were more likely to die within 10 days of birth (see Table 8). Each additional kilogram decreased the probability of death of full-term babies by 0.003 , a 21 percent decrease from the baseline mortality probability of $0.010 .^{11}$ But, despite their higher birth weights, full-term white babies were significantly more likely to die within 10 days of birth than black babies (see Table 8). Being white lowered a full-term baby's probability of survival by 0.005 controlling for birth weight, gestational age, and other characteristics. However, once I control for breast-feeding, being white lowered a baby's probability of survival by the statistically insignificant amount of 0.002 , suggesting that differences in breast feeding practices explain at least 60 percent of the difference in black-white survival rates.

The relationship between birth weight and death was not strictly linear. ${ }^{12}$ Compared to babies weighing over 2500 but less than 4500 grams, babies weighing more than 4500 grams had a probability of dying within the first 10 days of life that was greater by 0.29 . Babies weighing less than 2500 grams had a probability of death that was greater by 0.14 . The use of forceps was associated with a higher risk of death of the child, raising the probability of death by 0.01 . The

\footnotetext{
${ }^{10}$ Goldin and Margo (1989) did not find a statistically significant effect of season of birth on birth weight in the Philadelphia Almshouse. Ward (1993: 62) found that babies born in Vienna in the fall during the crisis years of 1916-1922 had higher birth weights than those born in other months. In the Johns Hopkins data the proportion of full-term births occurring in the spring was the lowest among blacks, but among whites the lowest proportion occurred in the fall. Either preferences or seasonality across occupations are potential explanations.

${ }^{11}$ This baseline probability is higher than that reported in Table 2 because this sample excludes observations where the type of feeding is unknown.

${ }^{12}$ Controlling for non-linearities does not affect black-white survival differences.
} 
results suggest that birth injury was an important determinant of surviving the first ten days of life, consistent with evidence from New York Lying-In (Costa 1998) and from the Philadelphia Almshouse (Goldin and Margo 1989).

The effects of feeding practices are evident in weight gain in the first 10 days of life. White babies gained less weight than black babies, even controlling for birth weight (not shown). But, controlling for feeding practices explains 21 percent of the difference in black-white weight gain. Babies fed formula only lost 247 grams relative to babies fed breast-milk only. Babies fed a combination of breast-milk and formula lost 130 grams relative to babies fed breast-milk only. At the beginning of the century, the prevalence of breast feeding was falling both in the Johns Hopkins sample and in the United States as a whole (Apple 1987), thereby leading to less weight gain among babies born in the 1920s or later relative to babies born earlier.

The data do not allow me to determine whether it was breast feeding per se that was beneficial to children or whether breast feeding was associated with more frequent feeding. At New York Lying-In insufficient feeding, not the type of feeding, predicted poor weight gain (Costa 1998). Babies born in the winter experienced poorer weight gain compared to babies born in the summer. When the seasons are divided into quarters, babies born in the second and third quarters (April-September) fare better than babies born in the fourth quarter (October-December).

The relatively good fortune of black babies in the first ten days of life spent in the hospital probably did not outlast their stay. The Children's Bureau study of infant mortality in Baltimore in 1915 revealed a steep gradient between infant mortality and family income, because a higher income enabled families to buy lower room congestion, sanitary equipment, and less work away from home for the pregnant mother (Rochester 1923).

A relatively large proportion of the black-white gap in prematurity rates, stillbirth rates, and birth weights still remains unexplained - two-thirds of the black-white prematurity gap, 59 percent of the black-white stillbirth gap, and 91 percent of the black-white full-term 
birth weight gap. These differences cannot be explained by socioeconomic differentials. Using the small subsample that contains socioeconomic information shows that controlling for either father's occupational status or income does not affect differences in prematurity or stillbirth rates. Controlling for father's occupational status or income increases the unexplained birth weight advantage of full-term white babies.

\section{Birth Outcomes and Race in 1988}

Such social factors as the mother's marital status play a much more important role today than in the past in explaining black-white differences in rates of prematurity and in birth weight. Table 10 shows that differences in marital status explain 16 percent of the black-white difference in prematurity rates. Other observable factors have very little effect on prematurity rates. Marital status is also a statistically significant predictor of birth weight and explains 10 percent of the black-white difference in birth weights (see Table 11). Controlling for parity, the sex of the child, the mother's age, her use of prenatal care, whether the mother was foreign-born, maternal smoking and alcohol use, maternal education, and maternal height has no effect on the black-white birth weight gap (not shown). However, once I control for marital status, the birth weight gap falls from 307 to 280 grams for all births and from 210 to 188 grams for full-term births.

Maternal birth weight has a statistically significant on the child's birth weight. An extra 100 grams in maternal birth weight increases child birth weight by 16 grams for all births and by 14 grams for full-term births. In a probit in which the dependent variable is whether the full-term child weighed less than 2500 grams at birth, each kilogram of maternal birth weight lowers the probability of low birth weight by 0.008 . In the OLS regressions racial differences in maternal birth weight explain roughly 5 percent of the difference in black-white birth weights both for all births and for full-term births. If I control for maternal birth weight prior to controlling for 
marital status, prematurity or gestational age, or maternal weight gain, then birth weight accounts for 8 percent of the difference in black-white birth weights. Maternal birth weight was not a statistically significant predictor of prematurity.

Prematurity was the most important predictor of birth weight for all births. Differences in prematurity rates explain roughly 32 percent of the black-white weight gap for all births. For full-term births, gestational age explains only 7 percent of the black-white gap (regression not shown), roughly comparable to the 8 percent that is explained by differences in maternal weight gain.

Including the logarithm of total household income (not shown) can further explain the black-white birth weight difference, but the effects are small. (Controlling for income in the prematurity regressions yields a small and insignificant coefficient on income and only a very small reduction in the black-white birth prematurity gap.) For all births, the coefficient on income was insignificant $(\hat{\beta}=19.557, \hat{\sigma}=14.889)$ and reduced the coefficient on the white dummy from 165.9 to 159.1 , thus suggesting that income differences explain only up to 2 percent of the blackwhite birth weight difference. For full-term births, the coefficient on income was statistically significant at the 10 percent level $(\hat{\beta}=22.414, \hat{\sigma}=13.743)$ and reduced the coefficient on the white dummy from 146.4 to 139.4 , thus implying that income differences account for 3 percent of the black-white birth weight differential.

The richer control variables available in the NMIHS compared to the Johns Hopkins data do not permit me to explain a greater proportion of the black-white gap in prematurity rates. Two-thirds of the gap is still unexplained. However, because I can control for maternal weight gain and maternal birth weight in the NMIHS, I can explain up to 30 percent of the black-white difference in birth weights, leaving only 70 percent unexplained compared to 91 percent unexplained in the Johns Hopkins sample. Future research may need to focus on better measures of the mother's early life and current health status, on her current nutritional status, and 
on her sources of familial support. For example, among low-income pregnant women, zincintake is lower among blacks than among whites (Neggers et al. 1998). Racial differences in ascending infection and upper genital tract colonization of the chorioamnionic interface may help explain racial differences in premature births (Goldenberg et al. 1996).

\section{Conclusion}

Over the twentieth century the differential in black-white pregnancy outcomes has been persistent. Differences in prematurity rates account for the biggest observable share of the black-white gap in birth weights, both in the past and today. Some of the persistence in the birth weight gap may be explained by intergenerational factors. Intergenerational factors, as proxied by maternal birth weight, accounted for 5 to 8 percent of the gap in recent data, implying that the role of maternal birth weight is as important as that of maternal weight gain and is much larger than that of family income. But, many of the explanations for relatively poor outcomes of black pregnancies have changed. In the early twentieth century untreated syphilis was the primary observable explaining differences in black-white prematurity and stillbirth rates. Today the primary observable explaining differences in prematurity rates is the low marriage rate of black women, a significant social change that dates from the 1960s. Differential marriage rates also play an important role in explaining the recent black-white birth weight gap.

Trends in birth weights, including those of full-term births, by race have remained roughly constant over the twentieth century and prematurity rates have increased slightly since the 1960s. In contrast, stillbirth and infant mortality rates fell sharply, coincident with declines in infectious disease in the first half of the twentieth century and improvements in the technology of 
birth in the second half of the twentieth century. ${ }^{13}$ Birth weights in the past may have compared favorably with those today because many low-birth-weight babies who were stillborn in the past would have survived with modern obstetrical knowledge and a modern disease environment. The constancy in live birth weights over the twentieth century suggests that explanations for improvements in health at older ages may need to focus either on other measures of intrauterine growth retardation or on changes in the disease environment, changes that affected all age groups but that were particularly important in the first five years of life.

\section{Data Appendix}

The Johns Hopkins sample consists of 1911 births, including still-births and infant deaths. The first step in the construction of the sample was the creation of indexes of births that occurred at the Johns Hopkins Hospital or through the Johns Hopkins Out-door Obstretical Department between 1897 and 1935. Random samples of births were then drawn from the two indexes in proportion to the size of the two indexes. 1472 hospital births and 990 out-door births were selected for a total sample size of 2462 births. However, only 1911 births were then found among the births records because all births for the same mother at Johns Hopkins Hospital are filed together with that mother's last birth. Thirty-seven percent of births from the hospital sample could not be found and two percent of births from the home births sample could not be found. First-born children whose siblings were also born at Johns Hopkins Hospital have a lower probability of being found. Two hundred sibling birth records were also collected for mothers who delivered other children through Johns Hopkins Hospital, but these records were not used in the analysis.

Using sample weights that account for the over-representation of home births in the

\footnotetext{
${ }^{13}$ See Collins and Thomasson (2002) for an account of declines in infant mortality rates among both blacks and whites and the persistence of a racial gap.
} 
Johns Hopkins sample does not materially change the results. Mean birth weights are lower by only 20 to 30 grams. Table 1 presented both the unweighted and weighted results. The other tables are all unweighted.

The 1988 National Maternal and Infant Health Survey consists of separate random samples of national live birth, fetal deaths, and infant deaths linked to questionnaires mailed to mothers. The response rate on questionnaires was 74 percent for live births, 69 percent for fetal deaths, and 65 percent for infant deaths. Because fetal and infant deaths are over-sampled sample weights must be used to obtain national estimates. 


\section{References}

[1] Apple, Rima D. 1987. Mothers and Medicine: A Social History of Infant Feeding, 18901950. Madison, WI: University of Wisconsin Press.

[2] Barker, D.J.P. (Ed.) 1994. Mothers, Babies, and Disease in Later Life. London: British Medical Journal.

[3] Beardsley, Edward H. 1987. A History of Neglect: Health Care for Blacks and Mill Workers in the Twentieth Century South. Knoxville, TN: University of Tennessee Press.

[4] Brandt, Allan M. 1987. No Magic Bullet, A Social History of Venereal Disease in the United States Since 1880. New York-Oxford: Oxford University Press.

[5] Collins, William J. and Melissa A. Thomasson. 2002. "Exploring the Racial Gap in Infant Mortality Rates, 1920-1970.” NBER Working Paper No. 8836.

[6] Copper, Rachel L., Robert L. Goldenberg, Robert K. Creasy, Mary B. DuBard, Richard O. Davis, Stephen S. Entman, Jay D. Iams, and Suzanne P. Cliver. 1993. "A multicenter study of preterm birth weight and gestational age-specific neonatal mortality." American Journal of Obstetrics and Gynecology. 168(1): 78-84.

[7] Copper, R.L., R.L. Goldenberg, M.B. Dubard, and R.O. Davis. 1994. "Risk factors for fetal death in white, black, and Hispanic women. Collaborative Group on Preterm Birth Prevention." Obstetrics and Gynecology. 84(4): 490-5.

[8] Costa, Dora L. 1998. "Unequal at Birth: A Long-Term Comparison of Income and Birth Weight." Journal of Economic History. 58(4): 987-1009.

[9] Doblhammer, Gabriele and James W. Vaupel. 2001. "Lifespan depends on month of birth." Proceedings of the National Academy of Sciences. 98(5): 2934-9.

[10] Emanuel, Irvin, Haroulla Filakti Eva Alberman, and Stephen J.W. Evans. 1992. "Intergenerational studies of human birth weight from the 1958 birth cohort. 1. Evidence for a multigenerational effect." British Journal of Obstetrics and Gynaecology. 99: 67-74.

[11] Emanuel, Irvin, Wendy Leisenring, Michelle A. Williams, Christy Kimpo, Sharon Estee William O'Brien, and Christiane B. Hale. 1999. “The Washington State Intergenerational Study of Birth Outcomes: methodology and some comparisons of maternal birthweight and infant birthweight and gestation in four ethnic groups." Paediatric and Perinatal Epidemiology. 13: 352-71.

[12] Goldenberg, Robert L., Suzanne P. Cliver, Francis Mulvihill, Carol A. Hickey, Howard J. Hoffman, Lorraine V. Klerman, and Marilyn J. Johnson. 1996. "Medical, psychosocial, and behavioral risk factors do not explain the increased risk of low birth weight among black women." American Journal of Ostetrics and Gynecology. 175(11): 1317-24. 
[13] Goldin, Claudia and Robert A. Margo. 1989. "The Poor at Birth: Birth Weights and Infant Mortality at Philadelphia's Almshouse Hospital, 1848-1873." Explorations in Economic History. 26(3): 360-79.

[14] Louden, Irvine. 1992. Death in Childbirth: An International Study of Maternal Care and Mortality, 1800-1950. Oxford: Clarendon Press.

[15] Manton, Kenneth G. and Eric Stallard. 1997. "Health and Disability Differences Among Racial and Ethnic Groups." In Linda G. Martin and Beth J. Soldo, Editors, Racial and Ethnic Differences in the Health of Older Americans. Washington DC: National Academy Press: 43-104.

[16] Morton, Newton E. 1955. "The inheritance of human birth weight." Annals of Human Genetics. 20: 125-134.

[17] Neggers, Y.H., R.L. Goldenberg, S.P. Cliver, and R.L. Copper. 1998. "Determinants of zinc intake in low-income black and white pregnant women." Biological trace element research. 64(1-3): 221-8.

[18] Parran, Thomas. 1937. Shadow on the Land, Syphilis. New York: The American Social Hygiene Association and Reynal and Hitchcock, Inc.

[19] Petersson, Karin, Katarina Bremme, Roger Bottinga, Alexandra Hofsjö, Ingela HulthénVarli, Marius Kublickas, Margareta Norman, Nikos Papadogiannakis, Kjell Wanggren, and Kerstin Wolff. 2002. "Diagnostic evaluation of intrauterine fetal deaths in Stockholm 199899." Acta obstetricia et gynecologica Scandinavica. 81(4): 284-92.

[20] Preston, Samuel H., Mark E. Hill, and Greg L. Drevenstedt. 1998. "Childhood conditions that predict survival to advanced ages among African-Americans." Social Science and Medicine. 47(9): 231-46.

[21] Rochester, Anna. 1923. Infant Mortality: Results of a Field Study in Baltimore, MD. Based on Births in One Year. U.S. Department of Labor. Children's Bureau. Bureau Publication No. 119. Washington DC: Government Printing Office.

[22] Ruggles, Steven. 1994. "The Origins of African-American Family Structure.” American Sociological Review. 59(1): 136-51.

[23] Sanderson, Maureen, Irvin Emanuel, and Victoria L. Holt. 1995. "The intergenerational relationship between mother's birthweight, infant's birthweight, and infant mortality in black and white mothers." Paediatric and Perinatal Epidemiology. 9: 391-405.

[24] Smith, James P. and Raynard S. Kingston, 1997. "Race, Socioeconomic Status, and Health in Later Life." In Linda G. Martin and Beth J. Soldo, Editors, Racial and Ethnic Differences in the Health of Older Americans. Washington DC: National Academy Press: 105-62. 
[25] Speert, Harold. 1980. Obstetrics and Gynecology in America, A History. Baltimore, MD: Waverly Press.

[26] Steckel, Richard H. 1986. "Birth Weights and Infant Mortality among American Slaves." Explorations in Economic History. 23: 173-98.

[27] Tanner, James M. 1978. Fetus into Man: Physical Growth from Conception to Maturity. London: Open Books.

[28] United States Bureau of the Census. Historical Statistics of the United States, Colonial Times to 1970. Washington DC: GPO, 1975. Vital Statistics of the United States. Various Issues.

[29] Ward, W. Peter. 1993. Birth Weight and Economic Growth: Women's Living Standards in the Industrializing West. Chicago: University of Chicago Press. 
Table 1: Birth Weights (in Grams) by Race (Live Births), US

\begin{tabular}{|c|c|c|c|c|}
\hline Sample & Year & Mean & Median & $\begin{array}{c}\leq 2500 \mathrm{gm} \\
(\%)\end{array}$ \\
\hline U.S. slaves (inferred) & $1807-1864$ & 2330 & & \\
\hline Philadelphia Almshouse, white & $1848-1873$ & 3375 & 3453 & 8.1 \\
\hline Boston New England, white & $1872-1900$ & 3480 & & 6.5 \\
\hline Boston Lying-In, white (indoors) & $1886-1900$ & 3330 & & 6.9 \\
\hline Boston Lying-In, white (outdoors) & $1884-1900$ & 3479 & & 4.7 \\
\hline Boston Lying-In, black (indoors) & $1886-1900$ & 3126 & & 12.3 \\
\hline New York Lying-In, white (singletons) & $1910-1931$ & 3463 & 3467 & 5.5 \\
\hline Johns Hopkins, white (singletons) & $1897-1935$ & 3423 & 3443 & 6.0 \\
\hline weighted & & 3398 & 3415 & 6.4 \\
\hline Johns Hopkins, black (singletons) & $1897-1935$ & 3183 & 3175 & 11.4 \\
\hline weighted & & 3160 & 3175 & 11.9 \\
\hline US, white & 1950 & & 3320 & 7.2 \\
\hline US, nonwhite & 1950 & & 3250 & 10.4 \\
\hline US, white & 1960 & & 3340 & 6.8 \\
\hline US, nonwhite & 1960 & & 3150 & 12.8 \\
\hline US, white & 1970 & & 3330 & 6.9 \\
\hline US, black & 1970 & & 3120 & 13.9 \\
\hline US, white & 1980 & & 3410 & 5.7 \\
\hline US, black & 1980 & & 3170 & 12.5 \\
\hline US, white & 1990 & & 3410 & 5.7 \\
\hline US, black & 1990 & & 3170 & 13.3 \\
\hline US, white & 1998 & & 3390 & 6.5 \\
\hline US, black & 1998 & & 3180 & 13.0 \\
\hline National Maternal and Infant & & & & \\
\hline Health Survey, white (singletons) & 1988 & 3426 & 3430 & 5.1 \\
\hline National Maternal and Infant & & & & \\
\hline Health Survey, black (singletons) & 1988 & 3132 & 3203 & 12.3 \\
\hline
\end{tabular}

Note. Slave birth weights are from Steckel (1986) and are inferred from height at young ages. The data for the Philadelphia Almshouse are from Goldin and Margo (1989). The data from Boston are from Ward (1993: 148-149). The data for New York Lying-In are from Costa (1998). The data for the US are from various issues of Vital Statistics of the United States. Race is determined by the race of the mother. The weighted Johns Hopkins birth weights are more representative of the Johns Hopkins clientele (see the Data Appendix for details). 
Table 2: Differences in Outcomes at Johns Hopkins by Race

\begin{tabular}{lrrrr}
\hline \hline & \multicolumn{2}{c}{ All births } & \multicolumn{2}{c}{ Full-term births } \\
& White & \multicolumn{1}{c}{ Black } & White & Black \\
\hline Fraction premature & 0.065 & 0.130 & & \\
Fraction stillborn & 0.062 & 0.117 & 0.049 & 0.063 \\
Birth weight (gm), live and stillbirths & 3395.611 & 3097.299 & 3473.496 & 3265.941 \\
& $(649.637)$ & $(708.683)$ & $(544.094)$ & $(509.981)$ \\
Live births: & & & & \\
Birth weight (gm) & 3422.516 & 3182.896 & 3482.963 & 3270.997 \\
& $(621.017)$ & $(599.366)$ & $(536.784)$ & $(491.470)$ \\
Fraction weighing less than 2500 gm & 0.060 & 0.114 & 0.028 & 0.059 \\
Fraction live hospital births dead by day 10 & 0.076 & 0.046 & 0.041 & 0.012 \\
Weight by day 10 if born in hospital (gm) & 3305.695 & 3102.520 & 3324.894 & 3140.677 \\
& $(508.536)$ & $(536.166)$ & $(489.175)$ & $(491.249)$ \\
Weight gain by day 10 if born in hospital (gm) & -48.303 & -31.516 & -68.012 & 12.398 \\
& $(185.881)$ & $(198.729)$ & $(160.869)$ & $(167.325)$ \\
\hline \hline
\end{tabular}

The sample was restricted to singleton births. Standard errors in parentheses.

Table 3: Differences in Outcomes in National Maternal and Infant Health Survey by Race

\begin{tabular}{lrrrr}
\hline \hline & \multicolumn{2}{c}{ All births } & \multicolumn{2}{c}{ Full-term births } \\
& White & \multicolumn{1}{c}{ Black } & White & \multicolumn{1}{c}{ Black } \\
\hline Fraction premature & 0.066 & 0.172 & & \\
Fraction stillborn & 0.003 & 0.006 & 0.002 & 0.003 \\
Birth weight (gm), live and stillbirths & 3422.462 & 3126.461 & 3479.437 & 3254.671 \\
& $(581.535)$ & $(671.314)$ & $(502.541)$ & $(535.000)$ \\
Live births: & & & & \\
Birth weight (gm) & 3425.943 & 3132.148 & 3480.418 & 3256.185 \\
& $(575.873)$ & $(664.111)$ & $(500.972)$ & $(532.651)$ \\
Fraction weighing less than 2500 gm & 0.051 & 0.123 & 0.028 & 0.067 \\
Fraction dead by day 10 & 0.004 & 0.008 & 0.002 & 0.003 \\
\hline \hline
\end{tabular}

Standard errors in parentheses. Sample weights used in all calculations. The sample was restricted to singleton births. 
Table 4: Differences in Characteristics at Johns Hopkins by Race

\begin{tabular}{lrrrr}
\hline \hline & \multicolumn{2}{c}{ All births } & \multicolumn{2}{c}{ Full-term births } \\
& White & Black & White & Black \\
\hline Gestational age (weeks) & 39.452 & 37.804 & 39.869 & 38.605 \\
Parity & 2.097 & 2.046 & 2.099 & 2.136 \\
Dummy=1 if & & & & \\
$\quad$ child male & 0.503 & 0.507 & 0.506 & 0.506 \\
$\quad$ home birth & 0.480 & 0.531 & 0.489 & 0.548 \\
$\quad$ mother married & 0.875 & 0.766 & 0.880 & 0.782 \\
Number of prenatal visits & 2.622 & 3.252 & 2.669 & 3.412 \\
Mother's age & 26.179 & 24.356 & 26.216 & 24.485 \\
Dummy=1 if mother foreign-born & 0.480 & 0.117 & 0.488 & 0.114 \\
Dummy=1 if maternal syphilis & 0.019 & 0.127 & 0.014 & 0.090 \\
Dummy=1 if birth in & & & & \\
$\quad$ summer & 0.252 & 0.259 & 0.253 & 0.266 \\
$\quad$ fall & 0.204 & 0.253 & 0.207 & 0.255 \\
$\quad$ winter & 0.275 & 0.262 & 0.276 & 0.263 \\
$\quad$ spring & 0.269 & 0.226 & 0.264 & 0.216 \\
Dummy=1 if birth & & & & \\
$\quad$ before 1910 & 0.029 & 0.061 & 0.027 & 0.066 \\
$\quad$ in 1910s & 0.573 & 0.409 & 0.585 & 0.402 \\
$\quad$ in 1920s or later & 0.398 & 0.530 & 0.388 & 0.532 \\
If hospital birth: & & & & \\
Dummy=1 if forceps used & 0.090 & 0.100 & 0.099 & 0.108 \\
Dummy=1 if extraction & 0.086 & 0.090 & 0.089 & 0.084 \\
Observed length labor & 13.610 & 15.575 & 13.687 & 15.626 \\
Dummy=1 if fed & & & & \\
$\quad$ breast-milk & 0.704 & 0.774 & 0.714 & 0.806 \\
breast-milk and formula & 0.006 & 0.012 & 0.003 & 0.006 \\
formula only & 0.290 & 0.214 & 0.283 & 0.188 \\
\hline \hline
\end{tabular}

The sample was restricted to singleton births. 
Table 5: Differences in Characteristics in National Maternal and Infant Health Survey by Race

\begin{tabular}{lrrrr}
\hline \hline & \multicolumn{2}{c}{ All births } & \multicolumn{2}{c}{ Full-term births } \\
& White & \multicolumn{1}{c}{ Black } & \multicolumn{1}{c}{ White } & \multicolumn{1}{c}{ Black } \\
\hline Gestational age (weeks) & 39.523 & 38.462 & 39.977 & 39.764 \\
Parity & 2.245 & 2.562 & 2.249 & 2.552 \\
Dummy=1 if & & & & \\
$\quad$ child male & 0.527 & 0.503 & 0.527 & 0.499 \\
$\quad$ mother married & 0.820 & 0.368 & 0.826 & 0.382 \\
$\quad$ ever had prenatal visit & 0.989 & 0.966 & 0.989 & 0.970 \\
Mother's age & 26.543 & 24.369 & 26.596 & 24.478 \\
Dummy=1 if mother foreign-born & 0.102 & 0.078 & 0.100 & 0.081 \\
Dummy=1 if mother & & & & \\
$\quad$ smoker & 0.322 & 0.258 & 0.321 & 0.251 \\
$\quad$ high alcohol user & 0.053 & 0.064 & 0.051 & 0.061 \\
Dummy=1 if mother's education & & & & \\
$\quad$ less than high school & 0.120 & 0.259 & 0.117 & 0.250 \\
$\quad$ high school & 0.301 & 0.367 & 0.300 & 0.367 \\
$\quad$ some college & 0.175 & 0.143 & 0.177 & 0.150 \\
$\quad$ college & 0.135 & 0.064 & 0.136 & 0.069 \\
Mother's height (cm) & 188.967 & 194.872 & 189.586 & 194.711 \\
Mother's weight gain during pregnancy (gm) & 14428.63 & 13254.81 & 14596.10 & 13722.94 \\
Mother's birth weight & 3223.095 & 3088.193 & 3227.358 & 3100.966 \\
Child ever breast-fed & 0.581 & 0.268 & 0.590 & 0.283 \\
\hline \hline
\end{tabular}

Sample weights used in all calculations. The sample was restricted to singleton births. 
Table 6: Correlates of Prematurity and Stillbirths

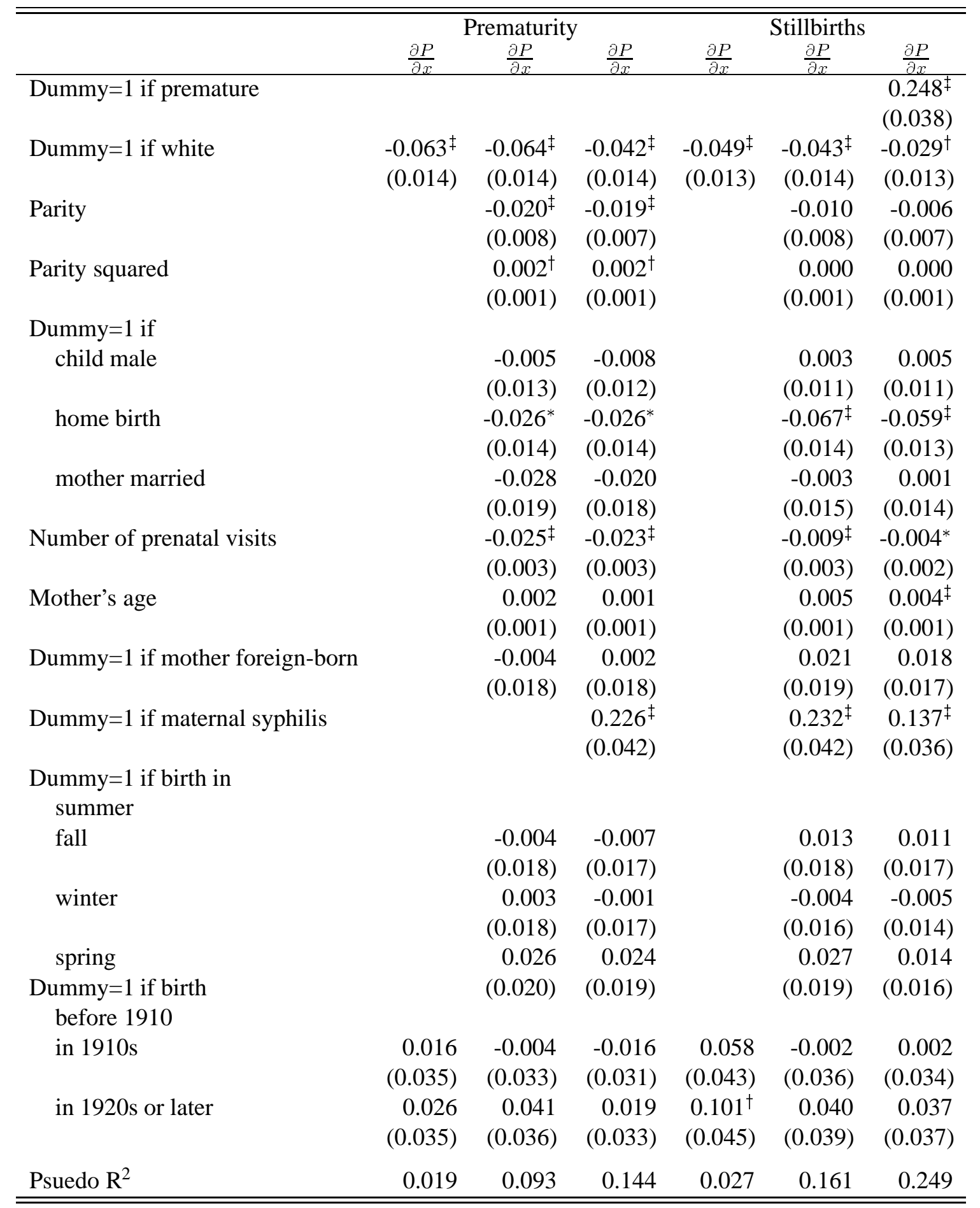

1729 observations. The sample was restricted to singleton births. The dependent variable for the regressions labeled prematurity is a dummy equal to one if the child was born prematurely. The dependent variable for the regressions labeled stillbirths is a dummy variable equal to one if the child was stillborn. Standard errors are in parentheses. The symbols $*$, $\uparrow$, and model. Derivatives for dummy variables give the change from 0 to 1 . 
Table 7: Correlates of Birth Weight (Live Births), Johns Hopkins

\begin{tabular}{|c|c|c|c|c|c|}
\hline \multirow{2}{*}{ Dummy $=1$ if premature } & \multicolumn{3}{|c|}{ All births } & \multicolumn{2}{|c|}{ Full-term births } \\
\hline & & & $\begin{array}{r}-1225.459^{\ddagger} \\
(54.637)\end{array}$ & & \\
\hline Gestational age (weeks) & & & & & $\begin{array}{r}21.518^{\ddagger} \\
(3.659)\end{array}$ \\
\hline Dummy $=1$ if white & $\begin{array}{r}238.725^{\ddagger} \\
(31.346)\end{array}$ & $\begin{array}{r}247.692^{\ddagger} \\
(33.789)\end{array}$ & $\begin{array}{r}204.102^{\ddagger} \\
(29.383)\end{array}$ & $\begin{array}{r}187.386^{\ddagger} \\
(28.420)\end{array}$ & $\begin{array}{r}170.758^{\ddagger} \\
(30.501)\end{array}$ \\
\hline Parity & & $\begin{array}{c}108.169 \ddagger \\
(17.891)\end{array}$ & $\begin{array}{r}87.502^{\ddagger} \\
(15.552)\end{array}$ & & $\begin{array}{r}87.272^{\ddagger} \\
(15.902)\end{array}$ \\
\hline Parity squared & & $\begin{array}{l}-6.951^{\ddagger} \\
(1.655)\end{array}$ & $\begin{array}{l}-5.115^{\ddagger} \\
(1.439)\end{array}$ & & $\begin{array}{c}-4.744^{\ddagger} \\
(1.482)\end{array}$ \\
\hline $\begin{array}{l}\text { Dummy }=1 \text { if } \\
\text { child male }\end{array}$ & & $\begin{array}{r}99.454^{\ddagger} \\
(29.252)\end{array}$ & $\begin{array}{r}96.134^{\ddagger} \\
(25.383)\end{array}$ & & $\begin{array}{r}102.291^{\ddagger} \\
(26.187)\end{array}$ \\
\hline home birth & & $\begin{array}{r}145.409^{\ddagger} \\
(33.523)\end{array}$ & $\begin{array}{r}121.731^{\ddagger} \\
(29.108)\end{array}$ & & $\begin{array}{r}119.939^{\ddagger} \\
(30.047)\end{array}$ \\
\hline mother married & & $\begin{array}{r}35.115 \\
(42.934)\end{array}$ & $\begin{array}{r}-2.985 \\
(37.293)\end{array}$ & & $\begin{array}{r}17.912 \\
(38.617)\end{array}$ \\
\hline Number of prenatal visits & & $\begin{array}{r}29.067^{\ddagger} \\
(6.940)\end{array}$ & $\begin{array}{r}7.541 \\
(6.098)\end{array}$ & & $\begin{array}{r}-2.544 \\
(6.323)\end{array}$ \\
\hline Mother's age & & $\begin{array}{r}-1.204 \\
(3.364)\end{array}$ & $\begin{array}{r}0.157 \\
(2.920)\end{array}$ & & $\begin{array}{r}0.333 \\
(3.030)\end{array}$ \\
\hline Dummy $=1$ if mother foreign-born & & $\begin{array}{r}-16.819 \\
(39.228)\end{array}$ & $\begin{array}{r}0.565 \\
(34.048)\end{array}$ & & $\begin{array}{r}-1.877 \\
(35.235)\end{array}$ \\
\hline Dummy $=1$ if maternal syphilis & & $\begin{array}{r}-195.136^{\ddagger} \\
(65.745)\end{array}$ & $\begin{array}{r}-79.993 \\
(57.279)\end{array}$ & & $\begin{array}{r}-66.098 \\
(61.259)\end{array}$ \\
\hline $\begin{array}{l}\text { Dummy }=1 \text { if birth in } \\
\text { summer }\end{array}$ & & & & & \\
\hline fall & & $\begin{array}{r}-19.592 \\
(42.129)\end{array}$ & $\begin{array}{r}-49.699 \\
(36.581)\end{array}$ & & $\begin{array}{r}-10.459 \\
(37.462)\end{array}$ \\
\hline winter & & $\begin{array}{r}-51.752 \\
(40.217)\end{array}$ & $\begin{array}{l}-58.759^{*} \\
(34.898)\end{array}$ & & $\begin{array}{r}-25.957 \\
(36.096)\end{array}$ \\
\hline spring & & $\begin{array}{l}-86.381^{\dagger} \\
(41.542)\end{array}$ & $\begin{array}{l}-80.751^{\dagger} \\
(36.047)\end{array}$ & & $\begin{array}{r}-73.102^{\ddagger} \\
(37.779)\end{array}$ \\
\hline $\begin{array}{l}\text { Dummy }=1 \text { if birth } \\
\text { before } 1910\end{array}$ & & & & & \\
\hline in $1910 \mathrm{~s}$ & $\begin{array}{l}-40.271 \\
(75.139)\end{array}$ & $\begin{array}{r}63.658 \\
(73.365)\end{array}$ & $\begin{array}{r}63.411 \\
(63.660)\end{array}$ & $\begin{array}{l}-50.857 \\
(68.504)\end{array}$ & $\begin{array}{r}73.861 \\
(66.076)\end{array}$ \\
\hline in 1920 s or later & $\begin{array}{r}-84.438 \\
(74.986)\end{array}$ & $\begin{array}{r}-4.870 \\
(77.897)\end{array}$ & $\begin{array}{r}41.706 \\
(67.624)\end{array}$ & $\begin{array}{r}-53.755 \\
(68.365)\end{array}$ & $\begin{array}{r}132.464^{*} \\
(70.664)\end{array}$ \\
\hline Constant & $\begin{array}{r}3243.942^{\ddagger} \\
(72.030)\end{array}$ & $\begin{array}{r}2840.130^{\ddagger} \\
(105.889)\end{array}$ & $\begin{array}{r}3009.661^{\ddagger} \\
(92.192)\end{array}$ & $\begin{array}{r}3327.021^{\ddagger} \\
(65.730)\end{array}$ & $\begin{array}{r}2111.418^{\ddagger} \\
(175.892)\end{array}$ \\
\hline Adjusted $\mathrm{R}^{2}$ & 0.039 & 0.138 & 0.351 & 0.031 & 0.156 \\
\hline
\end{tabular}

The entire sample contains 1546 observations and the sample of full-term births 1324 observations. The sample was restricted to singleton births. The dependent variable is birth weight. Coefficients are from an ordinary least squares regression. Standard errors are in parentheses. The symbols $*, \uparrow$, and $\stackrel{\dagger}{\dagger}$ indicate significance at the 10,5 , and 1 percent level, respectively. 
Table 8: Correlates of Death by Day 10 in Johns Hopkins Hospital Sample

\begin{tabular}{lrcrcrc}
\hline \hline & \multicolumn{2}{c}{ All births } & \multicolumn{3}{c}{ Full-term births } \\
& \multicolumn{2}{c}{ Std } & \multicolumn{2}{c}{ Std } & Std \\
& $\frac{\partial P}{\partial x}$ & Err & $\frac{\partial P}{\partial x}$ & Err & $\frac{\partial P}{\partial x}$ & Err \\
\hline Dummy=1 if white & 0.0352 & 0.0278 & $0.0046^{*}$ & 0.0045 & 0.0021 & 0.0029 \\
Birth weight (kg) & $-0.0601^{\ddagger}$ & 0.0221 & $-0.0051^{\dagger}$ & 0.0047 & $-0.0031^{\dagger}$ & 0.0036 \\
Dummy=1 if premature & $0.4086^{\ddagger}$ & 0.0828 & & & & \\
Gestational age (weeks) & & & -0.0002 & 0.0003 & -0.0001 & 0.0002 \\
Dummy=1 if breast-fed & & & & & $-0.0048^{\dagger}$ & 0.0061 \\
Parity & 0.0005 & 0.0147 & & & & \\
Parity squared & 0.0003 & 0.0016 & & & & \\
Dummy=1 if & & & & & & \\
$\quad$ child male & 0.0386 & 0.0238 & 0.0017 & 0.0025 & 0.0012 & 0.0019 \\
$\quad$ mother married & -0.0388 & 0.0308 & -0.0005 & 0.0023 & 0.0000 & 0.0013 \\
Number of prenatal visits & -0.0013 & 0.0049 & 0.0003 & 0.0005 & 0.0002 & 0.0004 \\
Mother's age & $0.0054^{\dagger}$ & 0.0024 & -0.0001 & 0.0002 & -0.0001 & 0.0001 \\
Dummy=1 if & & & & & & \\
$\quad$ mother foreign-born & 0.0076 & 0.0381 & & & & \\
$\quad$ maternal syphilis & $0.1298^{\ddagger}$ & 0.0599 & 0.0187 & 0.0286 & 0.0165 & 0.0265 \\
$\quad$ forceps used & 0.0370 & 0.0465 & $0.0154^{*}$ & 0.0181 & $0.0146^{\dagger}$ & 0.0176 \\
$\quad$ extraction & $0.2923^{\ddagger}$ & 0.0700 & -0.0001 & 0.0024 & -0.0006 & 0.0010 \\
Observed length labor (hours) & $0.0031^{\ddagger}$ & 0.0008 & 0.0000 & 0.0001 & 0.0000 & 0.0000 \\
Dummy=1 if birth in & & & & & & \\
$\quad$ summer & & & & & & \\
$\quad$ fall & -0.0076 & 0.0339 & 0.0008 & 0.0038 & 0.0013 & 0.0039 \\
$\quad$ winter & -0.0116 & 0.0318 & 0.0017 & 0.0042 & 0.0025 & 0.0047 \\
$\quad$ spring & 0.0244 & 0.0343 & 0.0014 & 0.0038 & 0.0019 & 0.0040 \\
Dummy=1 if birth in 1920s or later & $0.1089^{\ddagger}$ & 0.0241 & 0.0012 & 0.0025 & 0.0002 & 0.0015 \\
Pseudo R ${ }^{2}$ & 0.352 & & 0.278 & & 0.321 & \\
\hline \hline
\end{tabular}

The sample of all births contains 789 observations and the sample of full-term births contains 577 observations. The sample was restricted to live, singleton births born in the hospital. The dependent variable is a dummy equal to one if the child died by day 10 . The symbols $*, \uparrow$, and $\stackrel{+}{+}$ indicate significance at the 10,5 , and 1 percent level, respectively. Derivatives are from a probit model. Derivatives for dummy variables give the change from 0 to 1 . 
Table 9: Correlates of Weight Gain by Day 10 in Johns Hopkins Hospital Sample

\begin{tabular}{|c|c|c|c|c|c|c|}
\hline & $\begin{array}{l}\text { Coef- } \\
\text { icient }\end{array}$ & $\begin{array}{l}\text { Std } \\
\text { Err }\end{array}$ & $\begin{array}{l}\text { Coef- } \\
\text { icient }\end{array}$ & $\begin{array}{l}\text { Std } \\
\text { Err }\end{array}$ & $\begin{array}{l}\text { Coef- } \\
\text { icient }\end{array}$ & $\begin{array}{l}\text { Std } \\
\text { Err }\end{array}$ \\
\hline Dummy $=1$ if white & $-86.541^{\ddagger}$ & 14.767 & $-76.183^{\ddagger}$ & 16.566 & $-60.032^{\ddagger}$ & 15.659 \\
\hline \multicolumn{7}{|l|}{$\begin{array}{l}\text { Dummy }=1 \text { if fed } \\
\text { breast-milk }\end{array}$} \\
\hline breast-milk and formula & & & & & $-130.278^{\ddagger}$ & 16.200 \\
\hline formula only & & & & & $-246.556^{\ddagger}$ & 89.840 \\
\hline Gestational age (weeks) & & & 2.566 & 2.236 & 1.375 & 2.101 \\
\hline Parity & & & $18.309^{*}$ & 9.555 & 12.810 & 9.076 \\
\hline Parity squared & & & $-2.232^{\dagger}$ & 1.075 & -1.374 & 1.019 \\
\hline \multicolumn{7}{|l|}{ Dummy $=1$ if } \\
\hline child male & & & -4.334 & 14.477 & -7.093 & 13.613 \\
\hline mother married & & & -2.919 & 17.589 & -7.065 & 16.512 \\
\hline Number of prenatal visits & & & 2.272 & 3.253 & 1.276 & 3.053 \\
\hline Mother's age & & & -2.100 & 1.676 & -1.065 & 1.585 \\
\hline \multicolumn{7}{|l|}{ Dummy $=1$ if } \\
\hline mother foreign-born & & & -24.637 & 22.180 & $-36.125^{*}$ & 20.832 \\
\hline maternal syphilis & & & 10.972 & 34.013 & 7.789 & 31.895 \\
\hline \multicolumn{7}{|l|}{$\begin{array}{l}\text { Dummy }=1 \text { if birth in } \\
\text { summer }\end{array}$} \\
\hline fall & & & -4.022 & 20.150 & -9.617 & 18.901 \\
\hline winter & & & $-38.351^{*}$ & 19.913 & $-40.879^{\dagger}$ & 18.682 \\
\hline spring & & & -4.022 & 20.577 & -16.166 & 19.339 \\
\hline Dummy $=1$ if birth in 1920 s or later & $-32.732^{\dagger}$ & 14.852 & $-34.781^{*}$ & 18.133 & -14.898 & 17.158 \\
\hline Constant & $34.613^{\dagger}$ & 14.566 & -20.612 & 96.878 & 32.907 & 91.017 \\
\hline Adjusted R ${ }^{2}$ & 0.061 & & 0.066 & & 0.180 & \\
\hline
\end{tabular}

511 observations. The sample was restricted to live, singleton births born in the hospital. The dependent variable is weight gain (gm) during the first ten days. Coefficients are from an ordinary least squares regression. The symbols *, $\dagger$, and $\stackrel{\dagger}{\dagger}$ indicate significance at the 10,5 , and 1 percent level, respectively. 
Table 10: Correlates of Prematurity, 1988 National Maternal and Infant Health Survey

\begin{tabular}{|c|c|c|c|c|}
\hline & $\frac{\partial P}{\partial x}$ & $\frac{\partial P}{\partial x}$ & $\frac{\partial P}{\partial x}$ & $\frac{\partial P}{\partial x}$ \\
\hline \multirow[t]{2}{*}{ Dummy $=1$ if white } & $-0.117^{\ddagger}$ & $-0.112^{\ddagger}$ & $-0.094^{\ddagger}$ & $-0.091^{\ddagger}$ \\
\hline & $(0.014)$ & $(0.015)$ & $(0.017)$ & $(0.016)$ \\
\hline \multirow[t]{2}{*}{ Parity } & & 0.003 & 0.003 & 0.003 \\
\hline & & $(0.006)$ & $(0.006)$ & $(0.006)$ \\
\hline \multirow[t]{2}{*}{ Parity squared } & & 0.000 & 0.000 & 0.000 \\
\hline & & $(0.001)$ & $(0.001)$ & $(0.001)$ \\
\hline \multicolumn{5}{|l|}{ Dummy $=1$ if } \\
\hline \multirow[t]{2}{*}{ child male } & & 0.004 & 0.003 & 0.003 \\
\hline & & $(0.009)$ & $(0.009)$ & $(0.009)$ \\
\hline \multirow[t]{2}{*}{ mother married } & & & $-0.027^{*}$ & $-0.027^{*}$ \\
\hline & & & $(0.016)$ & $(0.016)$ \\
\hline \multirow[t]{2}{*}{ Mother's age } & & 0.001 & 0.002 & 0.002 \\
\hline & & $(0.001)$ & $(0.001)$ & $(0.001)$ \\
\hline \multicolumn{5}{|l|}{ Dummy $=1$ if mother } \\
\hline \multirow[t]{2}{*}{ ever had prenatal visit } & & $-0.052^{*}$ & -0.043 & -0.045 \\
\hline & & $(0.037)$ & $(0.035)$ & $(0.035)$ \\
\hline \multirow[t]{2}{*}{ foreign-born } & & -0.010 & -0.011 & -0.010 \\
\hline & & $(0.010)$ & $(0.010)$ & $(0.010)$ \\
\hline \multirow[t]{2}{*}{ smoker } & & 0.008 & 0.005 & 0.005 \\
\hline & & $(0.010)$ & $(0.011)$ & $(0.010)$ \\
\hline \multirow[t]{2}{*}{ high alcohol use } & & 0.022 & 0.017 & 0.019 \\
\hline & & $(0.024)$ & $(0.022)$ & $(0.022)$ \\
\hline \multirow{2}{*}{\multicolumn{5}{|c|}{$\begin{array}{l}\text { Dummy }=1 \text { if mother's education } \\
\text { less than high school }\end{array}$}} \\
\hline & & & & \\
\hline \multirow[t]{2}{*}{ high school } & & 0.003 & 0.004 & 0.004 \\
\hline & & $(0.012)$ & $(0.012)$ & $(0.012)$ \\
\hline \multirow[t]{2}{*}{ some college } & & -0.009 & -0.006 & -0.006 \\
\hline & & $(0.012)$ & $(0.013)$ & $(0.013)$ \\
\hline \multirow[t]{2}{*}{ college } & & -0.017 & -0.015 & -0.014 \\
\hline & & $(0.013)$ & $(0.013)$ & $(0.013)$ \\
\hline \multirow[t]{2}{*}{ Mother's height (cm) } & & 0.000 & 0.000 & 0.000 \\
\hline & & $(0.000)$ & $(0.000)$ & $(0.000)$ \\
\hline \multirow[t]{2}{*}{ Mother's birth weight (kg) } & & & & -0.013 \\
\hline & & & & $(0.008)$ \\
\hline Pseudo $\mathrm{R}^{2}$ & 0.026 & 0.033 & 0.036 & 0.038 \\
\hline
\end{tabular}

4528 observations used in the regressions. Sample weights used in all calculations. The sample was restricted to singleton births. The dependent variable is a dummy equal to one if the child was born before 37 weeks of gestation. Derivatives are from a probit model. Derivatives for dummy variables give the change from 0 to 1 . Standard errors in parentheses. The symbols $*, \dagger$, and $\ddagger$ indicate significance at the 10,5 , and 1 percent level, respectively. 
Table 11: Correlates of Birth Weight (Live Births), 1988 National Maternal and Infant Health Survey

\begin{tabular}{|c|c|c|c|c|c|c|c|c|}
\hline & \multicolumn{4}{|c|}{ All births } & \multicolumn{4}{|c|}{ Full-term births } \\
\hline $\begin{array}{l}\text { Dummy }=1 \text { if } \\
\text { premature }\end{array}$ & & & $\begin{array}{r}-900.755^{+} \\
(60.494)\end{array}$ & $\begin{array}{r}-889.006^{+} \\
(58.958)\end{array}$ & & & & \\
\hline $\begin{array}{l}\text { Gestational age } \\
\text { (weeks) }\end{array}$ & & & & & & & $\begin{array}{r}51.994^{\ddagger} \\
(6.026)\end{array}$ & $\begin{array}{r}52.157^{\ddagger} \\
(6.042)\end{array}$ \\
\hline Dummy $=1$ if white & $\begin{array}{r}307.050 \div \\
(24.469)\end{array}$ & $\begin{array}{r}280.038^{\ddagger} \\
(28.609)\end{array}$ & $\begin{array}{r}180.561^{\ddagger} \\
(29.907)\end{array}$ & $\begin{array}{r}165.917^{\ddagger} \\
(29.227)\end{array}$ & $\begin{array}{r}210.326^{+} \\
(25.113)\end{array}$ & $\begin{array}{l}187.798^{\ddagger} \\
(28.829)\end{array}$ & $\begin{array}{l}155.963^{\ddagger} \\
(27.716)\end{array}$ & $\begin{array}{l}146.428^{\ddagger} \\
(27.419)\end{array}$ \\
\hline Parity & & $\begin{array}{r}104.488^{\ddagger} \\
(23.702)\end{array}$ & $\begin{array}{l}110.856^{\ddagger} \\
(22.635)\end{array}$ & $\begin{array}{l}108.322^{\ddagger} \\
(22.381)\end{array}$ & & $\begin{array}{l}107.043^{\ddagger} \\
(22.078)\end{array}$ & $\begin{array}{l}138.127^{\ddagger} \\
(21.749)\end{array}$ & $\begin{array}{l}134.811^{\ddagger} \\
(21.477)\end{array}$ \\
\hline Parity squared & & $\begin{array}{l}-9.765^{\ddagger} \\
(3.317)\end{array}$ & $\begin{array}{r}-10.346^{\ddagger} \\
(2.991)\end{array}$ & $\begin{array}{l}-9.929^{\ddagger} \\
(2.976)\end{array}$ & & $\begin{array}{l}-8.917^{\ddagger} \\
(2.841)\end{array}$ & $\begin{array}{r}-13.356^{\ddagger} \\
(2.911)\end{array}$ & $\begin{array}{r}-12.818^{\ddagger} \\
(2.894)\end{array}$ \\
\hline $\begin{array}{r}\text { Dummy }=1 \text { if } \\
\text { child male }\end{array}$ & & $\begin{array}{l}114.425^{+} \\
(22.809)\end{array}$ & $\begin{array}{r}116.863^{\ddagger} \\
(22.988)\end{array}$ & $\begin{array}{r}115.176^{\ddagger} \\
(22.544)\end{array}$ & & $\begin{array}{r}125.227^{\ddagger} \\
(23.216)\end{array}$ & $\begin{array}{l}127.758^{\ddagger} \\
(22.210)\end{array}$ & $\begin{array}{r}126.244^{\ddagger} \\
(21.815)\end{array}$ \\
\hline mother married & & $\begin{array}{r}71.677^{\dagger} \\
(32.986)\end{array}$ & $\begin{array}{r}44.670 \\
(33.621)\end{array}$ & $\begin{array}{r}34.621 \\
(33.140)\end{array}$ & & $\begin{array}{r}59.945^{*} \\
(33.833)\end{array}$ & $\begin{array}{r}81.101^{\ddagger} \\
(33.062)\end{array}$ & $\begin{array}{r}68.874^{\dagger} \\
(32.789)\end{array}$ \\
\hline Mother's age & & $\begin{array}{r}-3.873 \\
(2.476)\end{array}$ & $\begin{array}{l}-2.241 \\
(2.525)\end{array}$ & $\begin{array}{r}-1.771 \\
(2.501)\end{array}$ & & $\begin{array}{l}-2.146 \\
(2.549)\end{array}$ & $\begin{array}{l}-0.375 \\
(2.449)\end{array}$ & $\begin{array}{r}-0.315 \\
(2.433)\end{array}$ \\
\hline Dummy $=1$ if mother & & & & & & & & \\
\hline $\begin{array}{l}\text { ever had prenatal } \\
\text { visit }\end{array}$ & & $\begin{array}{c}254.459^{*} \\
(137.545)\end{array}$ & $\begin{array}{c}175.035^{*} \\
(116.299)\end{array}$ & $\begin{array}{r}201.455 \\
(113.637)\end{array}$ & & $\begin{array}{r}56.161 \\
(127.928)\end{array}$ & $\begin{array}{r}70.926 \\
(112.359)\end{array}$ & $\begin{array}{r}106.807 \\
(111.502)\end{array}$ \\
\hline foreign-born & & $\begin{array}{r}-21.031 \\
(49.133)\end{array}$ & $\begin{array}{r}-61.255 \\
(48.447)\end{array}$ & $\begin{array}{r}-83.718 \\
(46.958)\end{array}$ & & $\begin{array}{r}-44.219 \\
(49.331)\end{array}$ & $\begin{array}{r}-65.482 \\
(50.187)\end{array}$ & $\begin{array}{r}-87.285^{*} \\
(48.936)\end{array}$ \\
\hline smoker & & $\begin{array}{r}-177.385^{\dagger} \\
(25.488)\end{array}$ & $\begin{array}{r}-172.325^{\ddagger} \\
(26.182)\end{array}$ & $\begin{array}{r}-167.710^{\ddagger} \\
(25.662)\end{array}$ & & $\begin{array}{r}-173.963^{\ddagger} \\
(26.388)\end{array}$ & $\begin{array}{r}-177.863^{\ddagger} \\
(25.614)\end{array}$ & $\begin{array}{r}-174.571^{\ddagger} \\
(25.195)\end{array}$ \\
\hline high alcohol use & & $\begin{array}{r}-57.050 \\
(58.573)\end{array}$ & $\begin{array}{r}-38.380 \\
(58.015)\end{array}$ & $\begin{array}{r}-53.090 \\
(57.256)\end{array}$ & & $\begin{array}{r}-24.549 \\
(60.306)\end{array}$ & $\begin{array}{r}-37.984 \\
(54.772)\end{array}$ & $\begin{array}{r}-51.259 \\
(53.805)\end{array}$ \\
\hline $\begin{array}{l}\text { Dummy=1 if mother's } \\
\text { education } \\
\quad<\text { high school }\end{array}$ & & & & & & & & \\
\hline high school & & $\begin{array}{l}-47.371 \\
(30.280)\end{array}$ & $\begin{array}{l}-44.355 \\
(30.929)\end{array}$ & $\begin{array}{l}-43.938 \\
(30.286)\end{array}$ & & $\begin{array}{l}-50.488 \\
(31.066)\end{array}$ & $\begin{array}{l}-49.916^{*} \\
(29.959)\end{array}$ & $\begin{array}{l}-50.626^{*} \\
(29.412)\end{array}$ \\
\hline some college & & $\begin{array}{r}42.584 \\
(32.542)\end{array}$ & $\begin{array}{r}37.042 \\
(32.462)\end{array}$ & $\begin{array}{r}35.597 \\
(31.981)\end{array}$ & & $\begin{array}{r}33.072 \\
(33.029)\end{array}$ & $\begin{array}{r}18.749 \\
(31.863)\end{array}$ & $\begin{array}{r}16.685 \\
(31.424)\end{array}$ \\
\hline college & & $\begin{array}{r}7.537 \\
(34.368)\end{array}$ & $\begin{array}{r}-5.641 \\
(33.764)\end{array}$ & $\begin{array}{r}-9.770 \\
(32.945)\end{array}$ & & $\begin{array}{r}-1.718 \\
(34.499)\end{array}$ & $\begin{array}{r}10.719 \\
(33.095)\end{array}$ & $\begin{array}{r}8.202 \\
(32.264)\end{array}$ \\
\hline Mother's height $(\mathrm{cm})$ & & $\begin{array}{r}0.992^{\ddagger} \\
(0.128)\end{array}$ & $\begin{array}{r}0.943^{\ddagger} \\
(0.129)\end{array}$ & $\begin{array}{r}0.744^{\ddagger} \\
(0.744)\end{array}$ & & $\begin{array}{r}0.936^{\dagger} \\
(0.131)\end{array}$ & $\begin{array}{r}0.850^{\ddagger} \\
(0.124)\end{array}$ & $\begin{array}{r}0.670^{\ddagger} \\
(0.127)\end{array}$ \\
\hline $\begin{array}{l}\text { Mother's weight gain } \\
\text { (gm) }\end{array}$ & & & & & & & $\begin{array}{l}0.015^{\ddagger} \\
(0.002)\end{array}$ & $\begin{array}{r}0.014^{\ddagger} \\
(0.002)\end{array}$ \\
\hline $\begin{array}{l}\text { Mother's birth weight } \\
\text { (gm) }\end{array}$ & & & & $\begin{array}{l}0.159^{\ddagger} \\
(0.022)\end{array}$ & & & & $\begin{array}{r}0.144^{\ddagger} \\
(0.021)\end{array}$ \\
\hline Constant & $\begin{array}{r}3125.260^{\ddagger} \\
(20.804)\end{array}$ & $\begin{array}{r}2604.668^{\ddagger} \\
(151.923)\end{array}$ & $\begin{array}{r}2812.499^{\ddagger} \\
(135.029)\end{array}$ & $\begin{array}{r}2326.617^{\ddagger} \\
(147.278)\end{array}$ & $\begin{array}{r}3275.256^{\ddagger} \\
(21.467)\end{array}$ & $\begin{array}{l}2906.299^{\ddagger} \\
(144.462)\end{array}$ & $\begin{array}{r}532.710^{\ddagger} \\
(273.513)\end{array}$ & $\begin{array}{r}95.951^{+} \\
(282.485)\end{array}$ \\
\hline $\mathrm{R}^{2}$ & 0.021 & 0.101 & 0.249 & 0.273 & 0.012 & 0.120 & 0.202 & 0.229 \\
\hline
\end{tabular}

4203 observations in the all births sample and 2365 observations in the full-term births sample. The samples were restricted to live, singleton births. The dependent variable is birth weight. Coefficients are from an ordinary least squares regression. Sample weights used in all calculations. Standard errors in parentheses. The symbols $*, \dagger$, and $\ddagger$ indicate significance at the 10 , 5 , and 1 percent level, respectively. 
Figure 1: Fetal Death Rates by Race, 1918-1996

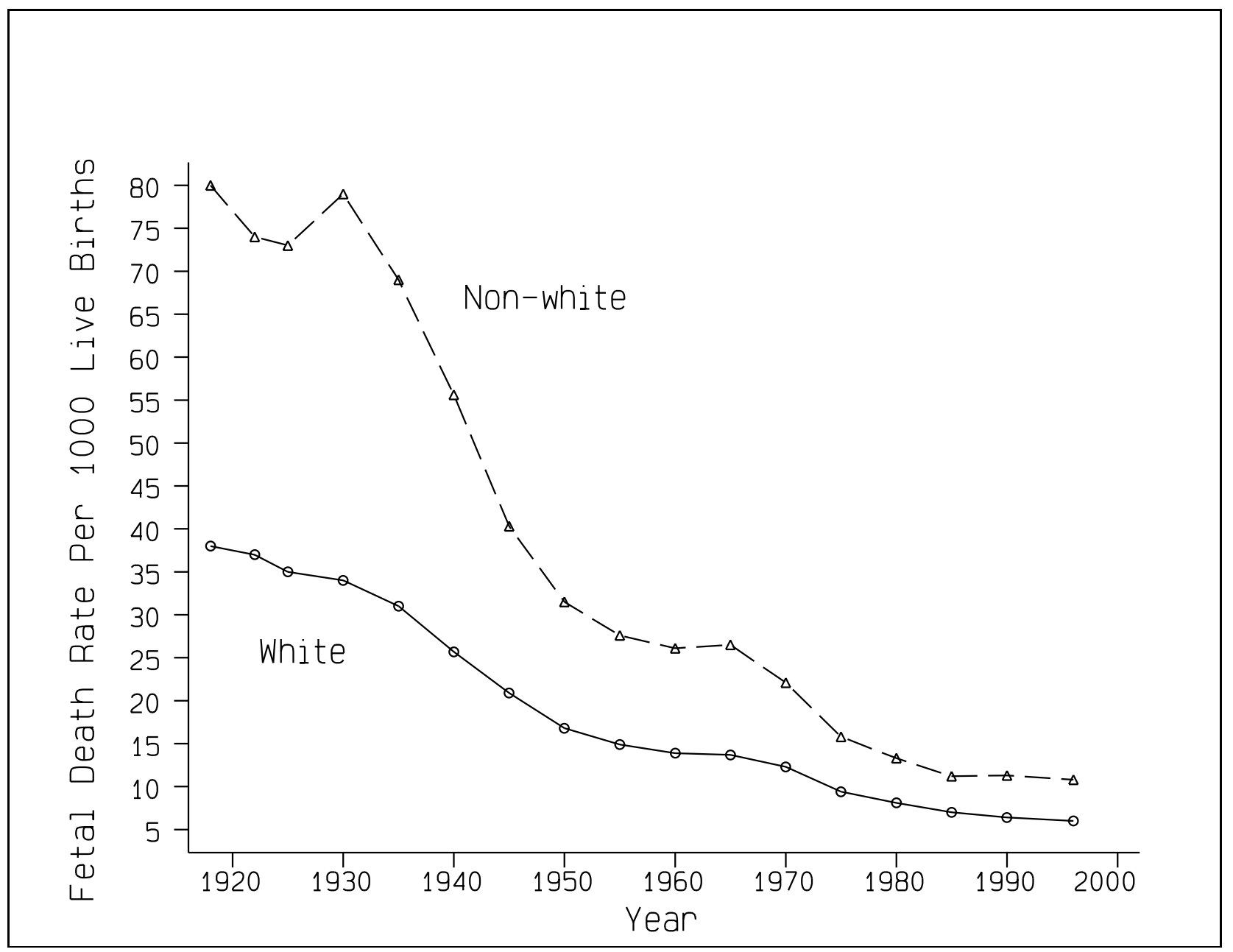

Source: Various issues of Birth statistics for the birth registration areas of the United States, Birth, stillbirth, infant mortality statistics, Birth, stillbirth, and infant mortality statistics for the continental United States, the territory of Hawaii, the Virgin Islands, and Vital Statistics of the United States. Fetal death rates are for the death registration states only. The period of gestation required for the registration of a stillbirth varied by year and by state. 